\title{
Elektronik Beton İzleme Sistemi Sonrası Yapı Denetimli Yapılarda Kullanılan Hazır Beton Kalitesinin Isparta İli Ölçeğinde Değerlendirilmesi
}

\author{
Evaluation Of Ready-Mixed Concrete Quality In Isparta Scale After Electronic Concrete \\ Monitoring System
}

\author{
Habib DOĞAN* \\ * Isparta Valiliği, Çevre ve Şehircilik İl Müdürlüğü, 32200, Isparta
}

• Geliş tarihi / Received: 03.04.2020 • Düzeltilerek geliş tarihi / Received in revised form: 17.09.2020 • Kabul tarihi / Accepted: 24.09 .2020

$\ddot{O} z$

Nüfusunun neredeyse tamamına yakını deprem riski içerisinde bulunan ülkemizde yapıların depreme dayanıklı olarak yapılması büyük önem arz etmektedir. Yapıların depreme dayanıklılığında belirleyici parametrelerin başında ise demir ve beton tasarımları gelmektedir. Hazır beton sisteminin ülkemizde yaygınlaşmasıyla beton kalitesinde büyük oranlarda iyileşmeler sağlanmış olmakla birlikte benzer ölçekteki depremlerde gelişmiş ülkelerdekine nazaran daha fazla hasarla karşılaşmamız, istenilen ölçüde kaliteyi yakalayamadığımızı göstermektedir. Bu amaçla Çevre ve Şehircilik Bakanlığı (ÇŞB) tarafından yapı denetimi kapsamında inşa edilen yapıların hazır beton denetimlerindeki suiistimalleri önlemek adına dünyada ilk defa beton numunelerinin elektronik olarak izlendiği bir sistem, Elektronik Beton İzleme Sistemi (EBİS) devreye sokulmuştur. Bu çalışmada 2019 yılında Isparta ilinde yapı denetim kapsamında numune alınarak teste tabi tutulan sonuçların değerlendirilmesi yapılmışıtır. Kullanılan tüm numuneler Radyo Frekansı ile Tanımlama (RFID) etiketleriyle alınmış C25/30, C30/37, C35/45 beton sınıfindaki 12650 adet hazır beton numunelerinden oluşmaktadır. Elde edilen sonuçların, Isparta'da yapı denetimli binalarda kullanılan hazır betonların basınç dayanım sonuçlarında bir sorun olmadığını göstermesine karşılık beton kalitesinde dikkate alınması gereken noktalarla karşılaşılmış ve bu hususlara vurgu yapılmıştır.

Anahtar kelimeler: Beton Basınç Dayanımı, EBİS, Hazır Beton, Yapı Denetim

\begin{abstract}
Almost all of the population of our country is at risk of earthquakes and it is of great importance that the structures are constructed to be earthquake resistant. Iron and concrete designs are the main determinant parameters of earthquake resistance of buildings. Although the ready-mixed concrete system has become widespread in our country and improvements in concrete quality have been achieved, the fact that we encounter more damage in similar earthquakes compared to developed countries shows that we have not achieved the desired quality yet. For this purpose, in order to prevent abuse of ready-mixed concrete inspections of buildings constructed by The Ministry of Environment and Urbanization (MEU) within the scope of building inspection, a system for monitoring concrete samples electronically (EBIS) was put into use for the first time in the world. In this study, in 2019, all the results which were tested in Isparta province were sampled and evaluated. The samples used consist of 12650 ready-mixed concrete samples in C25/30, C30/37, C35/45 concrete classes, all of which were taken with Radio Frequency Identification (RFID) tags. Although the results obtained show that there is no problem in the compressive strength results of ready-mixed concrete used in controlled buildings in Isparta, points to be considered in concrete quality have been encountered and these issues have been emphasized.
\end{abstract}

Keywords: Concrete Compressive Strength, ECMS, Ready-Mixed Concrete, Building Inspection

* Habib DOĞAN; habib.dogan@csb.gov.tr, Tel: (0246) 22413 00, orcid.org/ 0000-0001-8685-9569 


\section{Giriş}

Kalsiyum esaslı bağlayıcı maddelerin yapı malzemesi olarak kullanımı milattan önceki yıllara uzanmakla birlikte bildiğimiz anlamda ilk çimentonun patenti 1824 y1lında Joseph Aspdin tarafından alınmıştır. Daha sonraları Charles Johnson tarafından kil ve kireç karışımlarının kızdırma sıcaklıkları artırılarak bugünkü anlamında portland çimento elde edilerek aynı yüzyılda betonarme binalarda kullanılmaya başlanmıştır (Uğur ve Güleç, 2014). Çimento, su, agrega ve katk1 malzemelerinden oluşan beton, yap1 malzemelerinde en çok kullanılan bileşen özelliğini taşımaktadır. Hazırlanışı ve kullanımının kolaylığ 1 inşaatlarda kullanımını artıran faktörlerdendir. İlk olarak elle ya da mekanik olarak bileşenlerin karıştırılmasıyla elde edilen beton, daha sonraları otomatik olarak hazırlanmaya başlanmıştır. 20. Yüzyılın hemen başlarında ilk olarak Almanya ve ABD'de üretilmeye başlayan hazır beton gittikçe artan bir oranda yaygın kullanıma ulaşmıştır. Ülkemizde ise ilk olarak 1970 li yıllarda hazır beton üretimi yapılmış 1990'lı yıllarda yaygınlaşmıştır. Son y1llarda Türkiye y1llık üretim miktarının 100 milyon metreküp seviyesini aşmasıyla Avrupa lideri konumuna yükselirken, dünyada da Çin ve ABD'den sonra en büyük hazır beton üreticisi konumundadır (Akakın vd., 2013; URL-2, 2019).

Türkiye \%93'ü deprem kuşağında bulunan bir coğrafyadır. Meydana gelen büyük ölçekli depremlerde gelişmiş ülkelerdeki benzer büyüklükteki depremlere göre daha fazla kayıpların olması yapı kalitesinin düşük olmasindan kaynaklanan bir durum olarak görülmektedir. 1999 yılında yaşanan Marmara depremi sonrası Yapı Denetim Sistemi kurulmuş ve pilot illerde denenip değerlendirmeler yapıldıktan sonra 2011 y1lından itibaren tüm illere yaygınlaştırılmıştır. Yapı denetim firmaları inşaat faaliyetlerinin tüm aşamalarında denetim görevini yerine getirmekle yükümlü olduklarından beton dökümlerinin kontrolü de ÇŞB tarafından yetkilendirilmiş yapı laboratuvarları aracılığı ile yapı denetim firmaları tarafından yürütülmektedir. Laboratuvarlar tarafindan şantiye mahallinde alınan beton numuneleri 7 ve 28 gün kür havuzlarında bekletildikten sonra basınç dayanım testine tabi tutulmakta ve sonuçlar hakkında yap1 denetim firmaları bilgilendirilmektedir. Bu testler sonucu standartları sağlamayan beton test sonuçları hakkında karot alınarak tekrar değerlendirme yapılmakta, alınan karot sonuçlarına göre performans değerlendirmesi yapılarak projelerde öngörülen kriteleri sağlayıp sağlamadığı belirlenmektedir. Yap1 denetim sistemi gelmeden önceki hazır beton kalitesini değerlendirecek sonuçlara ancak hazır beton üretimi yapan firma kayıtlarından ulaşmak mümkün olduğu için bu konuda çok fazla bir çalışmaya rastlanılmamış olup, yapı denetim sistemi öncesi hazır beton verileri hakkında bilgiler sunan nadir çalışmalardan bazıları İstanbul, Antalya, Isparta ve Eskişehir illeri için yapılmıştır (Davraz vd., 2012; Topçu ve Demir, 2004; Topçu ve Boğa, 2005; Akyüz ve Uyan, 1989; Firat, 2005). Yap1 denetim sistemine geçildikten sonra kayıtların laboratuvarlar üzerinden erişilebilir olması birçok ildeki hazır betonların değerlendirmesiyle ilgili çalışmaların artmasıyla neticelenmiş ve Ankara, Afyonkarahisar, Osmaniye, Bolu, Sinop, Kastamonu ve Kütahya illerindeki hazır beton kalitesiyle ilgili çalışmalar yapılarak literatüre kazandırılmıştır (Topçu ve Uzunömeroğlu, 2019; Ergün ve Başaran, 2011; Öztoprak vd., 2018; Memiş vd., 2016; Dündar vd., 2017; Topçu ve Ateşin, 2013; Memiş vd., 2016b). Bu çalışmalarda genelde beton denetimlerini gerçekleştiren ve ÇŞB'na bağlı olarak çalışan yapı laboratuvarlarının kayıtları esas alınmış, bazılarında da Çevre ve Şehircilik İl Müdürlükleri (ÇŞM) tarafindan yapılan denetimler sonucu elde edilen veriler kullanılmıştır.

Kullanılan hazır betonun kalitesi ve performans1 yap1 ve tesislerin dinamik ve statik açıdan değerlendirilmesinde kullanılan parametrelerin başında gelmekte olup bu kalite, kullanılan çimento, agrega ile bunlar arasındaki kenetlenmeye bağlıdır. Yapıların kullanma amacına göre değişmekle birlikte betondan beklenilen en önemli performans onun basınç dayanımıdır. Bu yüzden, deprem anında dinamik yüklerin binmesi durumunda yapıların davranışını genel anlamda bu basınç dayanımı belirlemektedir (Memiş vd., 2016). Betonun kalitesi tasarım aşamasında başlayıp, üretim, taşıma, yerleştirme ve bakım peryotlarından oluşan bir süreç sonunda ortaya çkan bir kavram olup (Topçu ve Uzunömeroğlu, 2019), kaliteli malzeme, kapsamlı beton tesisleri, standartlara uygun tasarımların yap1lmas1, uygun üretim ve kontrol sisteminin oluşturulması gibi birçok değişkenlerin belirlediği bir parametredir (Öztoprak vd., 2018).

Hazır beton santrallerinin gelişmesiyle birlikte hızlı, daha kolay ve sürdürülebilir kalitede beton üretimi sağlanabilmektedir (Memiş vd., 2016b). Ülkemizde 2018 yılı verilerine göre hazır beton üretimi gerçekleştiren kurulu 495 firma ve 1100 hazır beton santrali mevcuttur (URL-1, 2019). Bu 
santraller yetkili kuruluşlarca sürekli denetlenmekte ve kalite süreçleri belgelendirilmektedir. Ayrıca ÇŞB taşra teşkilatı vasitasıyla hazır beton santrallerini belli periyotlarla sürekli denetlemekte ve Piyasa Gözetimi ve Denetimi (PGD) kapsamında aldığ1 numuneleri kendi laboratuvarlarında test ederek, standartlara uymayan üreticiler hakkında yasal yaptırımlara başvurmaktadır. Sektörün içerisinde aktif olarak bulunanların hazır beton testleri ile ilgili gördüğü en büyük problem laboratuvarların sahte beton sonuçları raporlamalarıdır (Topçu ve Uzunömeroğlu, 2019). Paydaşlardan gelen bu yoğun şikâyetler üzerine bakanlık dünyada ilk defa elektronik etiketlerin kullanıldığ sistemi geliştirerek 25.12.2018 tarihi itibariyle Elektronik Beton İzleme Sistemine (EBİS) geçmiştir. Tüm laboratuvarlara AselsanNET tarafından geliştirilen beton test kırım cihazları dağıtılmış ve şantiye mahallinde alınan numuneler içerisine RFID etiketler yerleştirerek, kırım sonuçlarının doğrudan merkeze aktarılması sağlanmışır. Beton Kırım Cihazı içerisine yerleştirilen kameralarla kırım süreci görüntülü olarak da kayıt altına alınmaktadır. Kırım sonuçlarına manuel bir müdahalenin mümkün olmamas1, hazır betonların kalite değerlendirmesinde EBİS çerçevesinde alınan betonların daha fazla fikir vereceği düşünülmekte, ayrıca sistemin elektronik olarak kayıt altında tutulması nedeniyle şantiye mahallinden geç alınma, kür havuzuna geç konulma, erken veya geç kırım yapma yahut da sonuçları değiştirme gibi ihtimalleri ortadan kaldirmasi sebebiyle de hazır beton kalitesi üzerinde pozitif bir etki yapacağı varsayılmaktadır.

Şekil 1'de elektronik beton izleme sistemi vasitasıyla gerçekleştirilen numune alma süreci gösterilmiştir. Şekil 1a'da şantiye mahallinde ÇŞB'nın genelgeleri doğrultusunda transmikserlerden numune alınması, Şekil $1 b$ 'de hem yap1 denetim elemanı hem de laboratuvar görevlisi nezaretinde numunelere RFID etiket yerleștirip kayıt altına alınması görülmektedir. Şekil 1c'de, şantiyede 16-72 saat arası bekletilen numunelerin taşınması, Şekil 1d'de 7 veya 28 günlük sürelerde havuzlarda numunelerin kürlenmesi, Şekil 1e'de ise bekletilen bu süreler sonunda otomatik olarak kırımın yapılıp sisteme yüklenmesi adımları gösterilmiştir (URL-3, 2020).

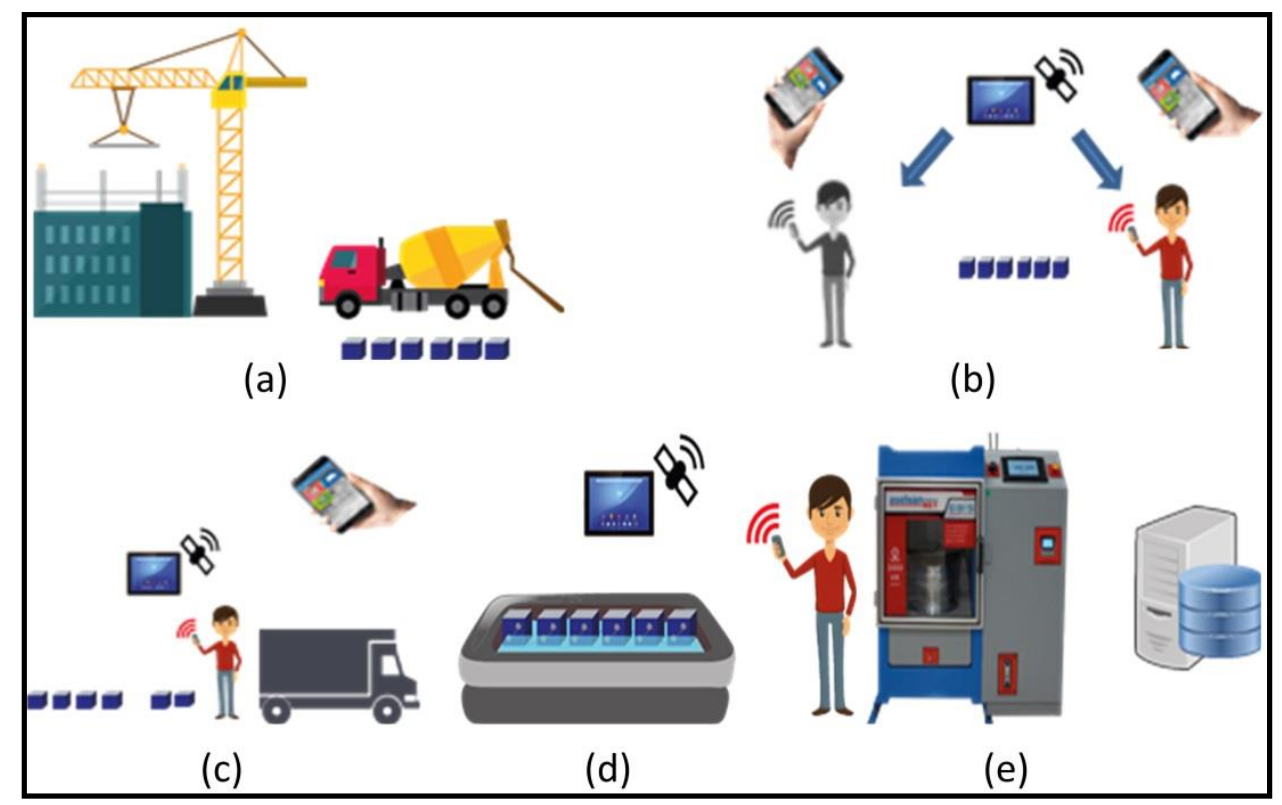

Şekil 1. Elektronik beton izleme sistemi vasıtasıyla numune alınma süreci(ebistr.com)

Isparta ili genel olarak büyük yer ivmelerine sahip bölgeler içerisinde yer almakta olup, tarihsel süreçte büyüklüğü 6.0'ın üzerinde olan depremlere yol açan ve halen aktif olan iki fay hattının arasında bulunmaktadır. Ayrıca yapılaşmanın genelde alüvyon zemin üzerine oturması bu bölgedeki depremlerin daha fazla hissedilmesine yol açmaktadır (Davraz vd., 2012). Betonarme binalarda sistemin en önemli iki elemanı beton ve donatıdır. Betonarme sistemin niteliği ve deprem anındaki davranışı da büyük oranda bu iki elemana bağlıdır. Türkiye'de farklı depremler sonrası yapilan araştırmalarda sorumluluğun büyük oranda beton basınç dayanımıyla alakalı olduğunu ortaya koyan çalışmalar bulunmaktadır (Uğurlu, 2013). Dolayısıyla piyasaya sürülen hazır betonların basınç dayanımlarının yönetmelik kriterlerini sağlayıp sağlamadığının sürekli olarak denetlenmesi gerekmektedir. 
Bu çalışmada 2019 yılı boyunca Isparta il merkezi ve ilçelerinde yap1 denetim kapsamında inşa edilen yapıların EBİS vasıtasıyla alınmış hazır beton test sonuçları değerlendirilmiştir. Isparta yerelinde faaliyet gösteren 7 farklı firmaya ait 11 hazır beton santralinde üretilen ve yıl boyunca alınan tüm sonuçlar çalışmaya dâhil edilerek istatistiksel metotlarla değerlendirilmeye tabi tutulmuş ve Isparta yöresi için hazır beton kalitesi hakkında fikir elde edilmeye çalışmıştır. 2. Bölümde çalışmanın yöntemleri verilmiş, elde edilen sonuçlar 3. Bölümde verilmiş ve bu sonuçların değerlendirilmesi ise 4. Bölümde yapılmıştır.

\section{Materyal ve Metot}

Isparta il merkezi ve ilçelerinde toplam 6 adet firmanın 13 adet hazir beton santrali mevcut olup bunlardan 4 adedi il merkezinde faaliyet gösterirken 7 adedi ise ilçelerde faaliyet göstermektedir. 2 santral ise 2019 y1lı içerisinde aktif olarak üretim yapmamıştır. İl merkezinde Çevre ve Şehircilik Bakanlığından izin almış 2 adet yap1 laboratuvarı mevcut olup tüm hazır beton numuneleri bu laboratuvarlar tarafindan alınmaktadır (URL-4, 2020). 25 Aralık 2018 tarihinden itibaren bu iki laboratuvara
AselsanNET tarafindan kırım cihazları kurulumu yapılmış ve gerekli teçhizat teslim edilmiştir. Yapı denetim firmaları tarafindan yapı denetim hizmet bedeli içerisinde yap1 sahibinden tahsil edilen bedelle temin edilen RFID etiketler anlaşmalı oldukları laboratuvarlara teslim edilmekte ve numune alımı sirasında yap denetim firmasindan elemanlar şahitliğinde kullanılmaktadır.

2019 yılı için bu laboratuvarlar tarafindan yapı denetimli yapıların denetimi kapsamında 1541 şantiyeden 12688 hazır beton numunesi alınmış ve kırım testleri gerçekleştirilmiştir. Tüm numuneler $15 \times 15 \times 15 \mathrm{~cm}$ boyutlarına sahip küp şeklindeki numune kapları ile alınmıştır. Bu test sonuçları kırım anında otomatik olarak EBİS merkez veri tabanına aktarılmakta ve www.ebistr.com adresinden erişime açılmaktadır. $\mathrm{Bu}$ çalışmada kullanılan sonuçlar ÇŞB'nın, İl Müdürlüklerindeki yap1 denetim sistemi kullanıcılarına vermiş olduğu rol çerçevesinde www.ebistr.com internet adresi üzerindeki verilere erişmek suretiyle elde edilmiştir. Şekil 2 de verilerin elde edildiği alan gösterilmiştir. Şekilden de görüleceği üzere sisteme 05.01.2020 tarihinde erişim sağlanmış ve aynı gün kırılan hazır beton sonuçları sistemde aktif olarak görülebilmektedir.

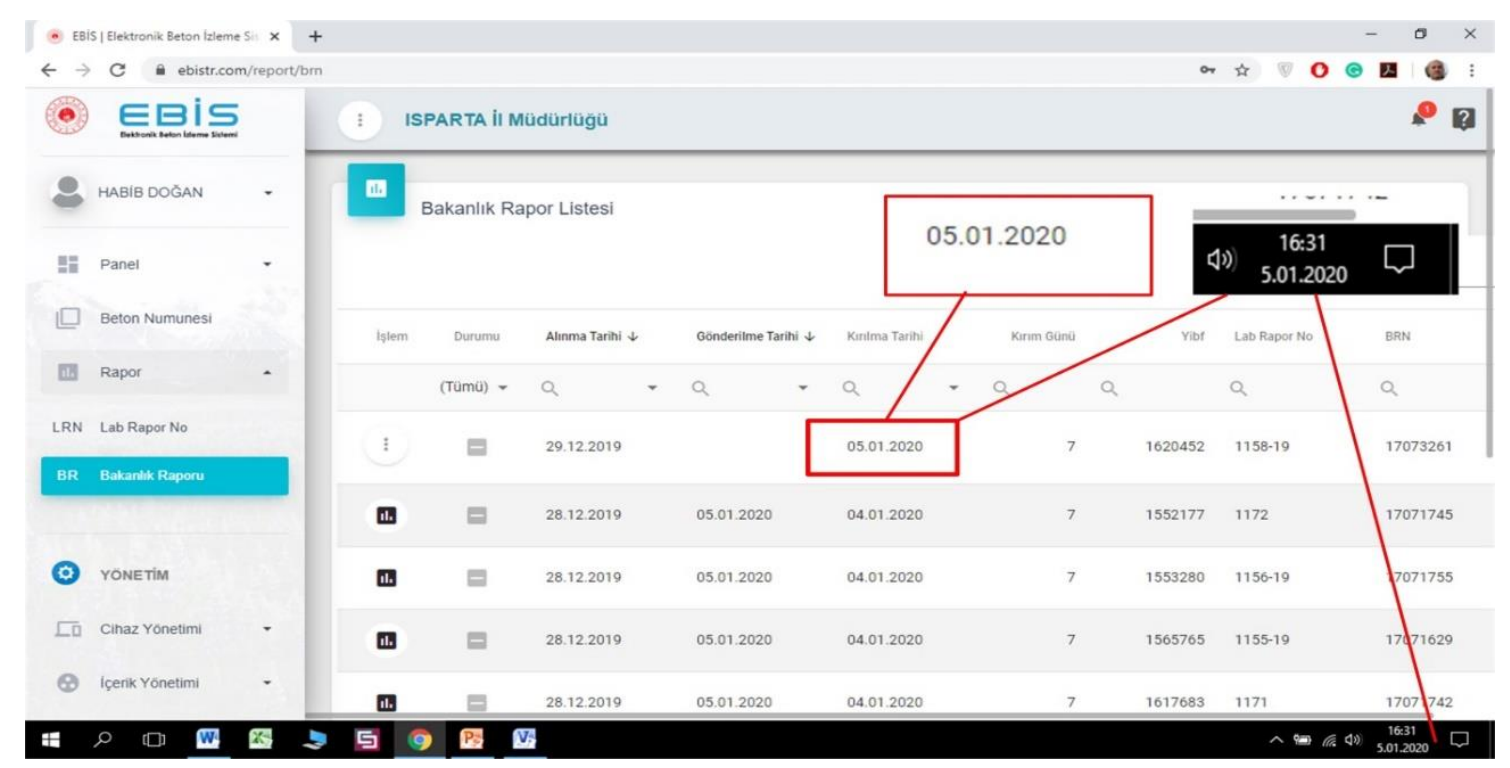

Şekil 2. Elektronik beton izleme sisteminde sonuçların izlenmesi (ebistr.com)

Sistemden elde edilen veriler işlenebilir forma dönüştürülüp, istatistiksel analizlere tabi tutulmuştur. Verilerin analizinde hazır beton testleri ile ilgili Türk Standartları (TSE, 2019) dikkate alınmış ve çıkan sonuçların kalite açısından değerlendirilmesinde de ACI (American Concrete Institute) kriterleri (ACI, 2011) kullanılmıştır. Değerlendirmeye alınan her üç grup beton sınıfi (C25/30, C30/37, C35/45) için ayrı ayrı standart sapmalar ve değişim katsayıları elde edilerek sonuçlar yorumlanmıştır. Standart sapma değerinin küçük çıkması üretilen hazır betonların ortalama değere yakın yoğunlukta üretildiğini ve kalitenin sürdürülebilirliğinin yüksek olduğunu, tam tersi durum ise betonlarda kalite açısından sıkıntıların varlığını göstermektedir (Dündar vd.,2017). Ülkemizde 2007 Deprem Yönetmeliğinde yapılarda 
kullanılabilecek en küçük beton sinıfi C20 olarak belirlenmişken, 2018 yönetmeliğinde bu değer C25 olarak belirlenmiştir (URL-2, 2018). Dolayısıyla elde edilen sonuçlardan, üretilen betonların basınç dayanımlarının bahsedilen yönetmelik kriterlerini ne oranda sağlayıp sağlamadığ 1 da görülebilecektir.

Alınan numunelerin beton basınç değerlerinin belirlenmesinde standart deney yöntemi kullanilmakta olup, bu yöntemde numuneler $15 \times 15 \times 15 \mathrm{~cm}$ boyutlarında küp ya da $15 \times 30 \mathrm{~cm}$ boyutlarında silindir kaplar kullanılarak alınmakta, 7 ve 28 günlük sürelerde sıcaklığı $+20 \pm 2{ }^{\circ} \mathrm{C}$ olan havuzlarda kürlemeye tabi tutulmakta ve bu süreler sonunda uniform basınç yükü altında basınç dayanımı testine tabi tutulmaktadır (Memiş vd., 2016). 28 günlük kırım sonuçlarının değerlendirilmesi, TSE 13515:2019 standardında verilen aşağıdaki kriterlere göre yapılmaktadır.

Tablo 1. Basınç dayanımı deney sonuçları ile denetim kriterleri

\begin{tabular}{ccc}
\hline $\begin{array}{c}\text { Belirli hacimdeki } \\
\text { betondan elde } \\
\text { edilen deney } \\
\text { sonucu adedi "n" }\end{array}$ & $\begin{array}{c}\text { 1. Kriter } \\
\text { "n" adet deney } \\
\text { sonucu ortalamas1 } \\
\left(f_{c m}\right) \mathrm{N} / \mathrm{mm}^{2}\end{array}$ & $\begin{array}{c}\text { 2. Kriter } \\
\text { Herhangi tek } \\
\text { deney sonucu } \\
\left(f_{i}\right) \mathrm{N} / \mathrm{mm}^{2}\end{array}$ \\
\hline 1 & Uygulanmaz & $\geq f_{c k}$ \\
$2-4$ & $\geq f_{c k}+1.0$ & $\geq f_{c k}-4.0$ \\
$\geq 5$ & $\geq f_{c k}+2.0$ & $\geq f_{c k}-4.0$ \\
\hline
\end{tabular}

Burada $f_{c k}$, o sınıf için belirlenmiş karakteristik basınç dayanım değerini gösterirken, $f_{c m}$, elde edilen ortalama basınç dayanım değeridir. Çevre ve Şehircilik Bakanlığının genelgesi doğrultusunda 17.05.2019 tarihine kadar her bir transmikserden 3 adet numune alınarak yapilan denetim, bu tarihten sonra her bir transmikserden

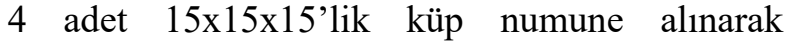
yapılmaktadır. 3 veya 4 adet şeklinde aynı transmikserden alınan numune seti bir deney seti olarak kabul edilmektedir. Bu numunelerden bir tanesi 7, diğer numuneler ise 28 günlük kürleme sonrası basınç dayanımı testine tabi tutulmaktadır. Değerlendirmeler tek bir deney seti üzerinden yapılabildiği gibi, o şantiyeden alınan tüm deney setleri üzerinden de yapılmaktadır. Değerlendirme sonucunun olumlu olması için her iki değerinde birlikte sağlanması gerekmektedir. TSE 13515:2019 standardının Ek B1 6. Maddesine göre; "beton basınç dayanımının uygunluğu, 28 gün yaşta deneye tabi tutulmuş numuneler üzerinde tayin edilir. Elde edilen beton basınç dayanımı sonuçlarının değerlendirilmesinde; aynı taze beton harmanından iki veya daha fazla sayıda deney numunesi hazırlandığında ve bu numunelerden elde edilen sonuçlardan herhangi birinin, ortalama sonuca göre sapmasının \% $\% 15$ 'den daha fazla olması durumunda, numune sonuçlarının hepsi reddedilir. Ancak, ikiden fazla numune olmasi durumunda, numuneler ve sonuçlar üzerinde yapılacak incelemeye göre sonuçlardan herhangi birinin ortalamaya dâhil edilmemesini haklı gösterecek bir sebep varsa yalnızca bu sonuç ortalamaya dâhil edilmez ve değerlendirmede geriye kalan numune sonuçları kullanılır (TSE, 2019). Böylece numune saklama, taşıma, kürleme veya uygun olmayan kırım şeklinden dolayı üreticinin mağdur olmasının önüne geçilmesi amaçlanmıştır.

Ayrıca TSE 13515:2019 standardının Ek B1 5. Maddesine göre bir şantiyede dökülen beton miktarına göre alınması gereken numune sayıları Tablo 2'de verilmiştir.

Tablo 2. Numune alma plan1

\begin{tabular}{lcc}
\hline $\mathbf{1 .}$ Kriter & 2. Kriter & $\begin{array}{c}\text { Numune alınacak asgari beton yükü veya } \\
\text { transmikser sayıs }\end{array}$ \\
\cline { 1 - 2 } $\begin{array}{c}\text { Üretim birimine giren beton } \\
\text { miktarı }\left(\mathrm{m}^{3}\right)\end{array}$ & $\begin{array}{c}\text { Üretim birimi için kat döşeme alanı veya } \\
\text { perde (tek yüzey) alanı }\left(\mathrm{m}^{2}\right)\end{array}$ & 2 \\
\hline $0-24$ & & 3 \\
$25-100$ & $<450$ & 4 \\
$101-150$ & $451-650$ & 5 \\
$151-200$ & $651-850$ & 6 \\
$201-250$ & $851-1050$ & 7 \\
$251-300$ & $1051-1250$ & 8 \\
$301-400$ & $1251-1450$ & 9 \\
$401-500$ & $1451-1650$ & 10
\end{tabular}
için yukarıdaki sayılara 1 ilave edilir.

Not - Numune alma işlemi, bütün imalâta yayılmalı ve numune alınan iki beton yükü (transmikser) arasında en az $25 \mathrm{~m}^{3}$ beton hacmi birakılmalıdır. 


\section{Bulgular}

Tablo 3'te Isparta ilinde 2019 y1lı içerisinde aylara göre dökülen beton miktarlarının sınıflara göre dağ 11 ımı verilmiştir. Bu tablo incelendiğinde, özellikle C35/45 beton sinıfindaki hazır beton kullanım miktarının il merkezinde oldukça yüksek miktarda olduğu ve Türkiye ortalamasının (\%25.5) üzerinde bir değerde kullanım oranına sahip olduğu görülmektedir (THHB, 2019). Y11 içerisinde toplam $125.896 \mathrm{~m}^{3}$ hazır beton kullanımı gerçekleşmiş olup, bu miktarın 100.819 $\mathrm{m}^{3}$ '̈̈ merkezde, kalan miktarı ise ilçelerde dökülmüştür. İl merkezinde sınıflara göre kullanımı sırasıyla C25/30 için \% 12, C30/37 için $\% 42$, C35/45 sınıfi için \%46 şeklindedir. İlçelerde ise \%56 gibi büyük bir oranda $\mathrm{C} 25 / 30$ sinıfi hazır beton kullanıldığ 1 , \%33 oranında C30/37, \%11 gibi çok küçük bir oranda da C35/45 sınıfi hazır beton kullanıldığı anlaşılmaktadır. İl merkezindeki C35/45 sinıfi hazır beton kullanımının yüksek miktarda olması kentsel dönüşüm projelerinin yoğun bir şekilde uygulanması ve uygulanan bu projelerdeki yapıların kat yüksekliğinin fazla olmasından kaynaklandığı düşünülmektedir.

Tablo 3. Isparta il ve ilçelerinde 2019 yılı içerisinde yapı denetimli binalarda kullanılan beton miktarları $\left(\mathrm{m}^{3}\right)$

\begin{tabular}{ccccccc}
\hline & \multicolumn{2}{c}{ C25/30 } & \multicolumn{2}{c}{ C30/37 } & \multicolumn{2}{c}{ C35/45 } \\
\hline Ocak & Merkez & İlçeler & Merkez & İlçeler & Merkez & İlçeler \\
Şubat & 95 & 145 & 2058.5 & 0 & 2054.24 & 0 \\
Mart & 935 & 780 & 3332.5 & 225 & 3095 & 1019 \\
Nisan & 782 & 2166 & 2900.23 & 1000 & 4748.22 & 363 \\
Mayıs & 233.2 & 1505 & 2515.24 & 1501.74 & 3936.8 & 63 \\
Haziran & 2427 & 1927 & 3765 & 962.24 & 4863.19 & 262 \\
Temmuz & 1653 & 683 & 2535 & 457 & 2931 & 333 \\
Ağustos & 1660 & 812 & 4880 & 441 & 4349.87 & 571 \\
Eylül & 2473 & 917.5 & 3290.22 & 641 & 2785 & 98 \\
Ekim & 390 & 1404 & 3947 & 842 & 3627.5 & 0 \\
Kasım & 115 & 1601.19 & 4867.5 & 651 & 5330.25 & 0 \\
Aralık & 323 & 1187 & 5321 & 611 & 4650.5 & 0 \\
\hline TOPLAM & $\mathbf{1 1 8 2 0 . 7 0}$ & $\mathbf{1 4 1 0 5 . 6 9}$ & $\mathbf{4 2 4 3 8 . 1 9}$ & $\mathbf{8 2 2 6 . 9 8}$ & $\mathbf{4 6 5 6 0 . 5 7}$ & $\mathbf{2 7 4 4 . 0 0}$ \\
\hline
\end{tabular}

Tablo 3'teki verilere bakıldığında Isparta'da 2019 y1lı içerisinde $126143 \mathrm{~m}^{3}$ hazır beton dökümü gerçekleştirilmiştir. Bu miktarın görece olarak azlığının 2019 yılındaki inşaat sektöründe yaşanan kriz kaynakl1 olduğu düşünülmektedir. Isparta genelinde 2017 y1lı için 832, 2018 y1lı için 525 adet inşaat ruhsatı (yapı denetim kapsamına giren) alınmışken bu sayı 2019 yılı için 140 adet gibi çok az bir rakamda kalmıştır. Bu 140 adet inşaat ruhsatının yaklaşık 100 adedi yılın son çeyreğinde alınmış olup çoğu inşaata başlamamış durumdadır. 2019 y1lı içerisinde dökülen tüm betonların il ve ilçelere göre dağılımı ise Şekil 3'te verilmiştir.

Şekil 3 incelendiğinde yapı denetimi kapsamındaki inşaatlarda dökülen betonların $\% 80$ gibi il merkezinde yoğunlaştığı görülmektedir. İlçe nüfuslarının düşük olması bu oranlarda etken husustur. Dört ilçe nüfusunun 5.000'nin altında kalması, $500 \mathrm{~m}^{2}$ ye kadar olan inşaatların yapı denetim dışında kalmasını netice vermektedir.

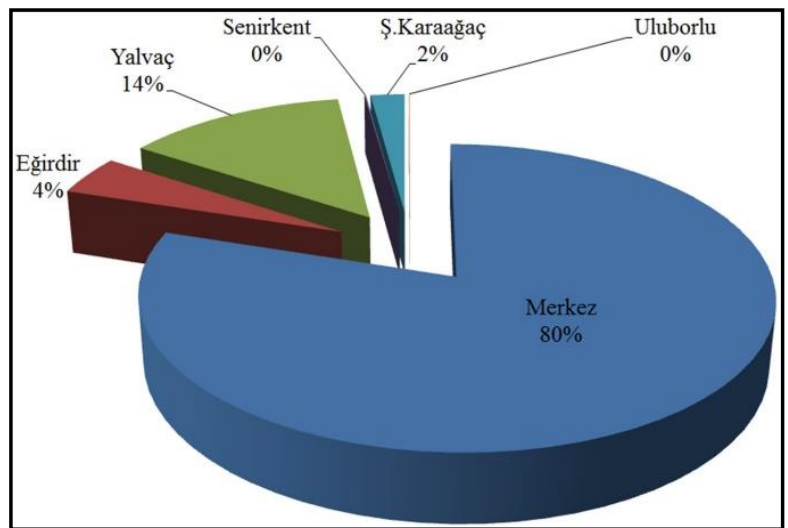

Şekil 3. Isparta genelinde dökülen beton miktarlarının il ve ilçelere göre dağılım yüzdesi

2019 yılı içerisinde hazır beton sınıfı bazında alınan numune sayıları ve istatistiksel değerlendirmeye ait veriler Tablo 4'te verilmiştir. $\mathrm{Bu}$ tablo incelendiğinde standart sapma değerlerinin yüksek olduğu, değişkenlik katsayısının da benzer şekilde yüksek değerlerde seyrettiği görülmektedir. $\mathrm{Bu}$ durum beton 
firmalarının üretiminde bir kalite sürekliliğinin zayıf olduğunu, minimum ve maksimum değerler arasinda beklenilenden fazla fark olduğunu göstermektedir. ACI 214R-11 değerlendirme kriterlerine göre $f_{c k} \leq 35 \mathrm{MPa}$ lik bir basınç dayanımına sahip olan siniflar standart sapma değerine bakılarak kalite sinıflandırılması yapılırken, $f_{c k} \geq 35 \mathrm{MPa}$ değerine sahip olan siniflar değişkenlik katsayısına bakılarak sınıflandırılır (ACI, 2011). Bu değerlendirme kriterlerine göre Isparta genelinde üretilen $\mathrm{C} 25 / 30$ betonların kalitesi "kötü" sınıfinda iken, C30/37 ve C35/45 sinifi betonların kaliteleri "orta" ve "iyi" seviyelerde çıkmaktadır.

Tablo 4. İl genelinde alınan tüm numunelerin istatistiksel verileri

\begin{tabular}{cccccccc}
\hline & $\begin{array}{c}\text { Alınan } \\
\text { Numune } \\
\text { Say1s1 }\end{array}$ & Ortalama & $\begin{array}{c}\text { Minimum } \\
\text { Değer }\end{array}$ & $\begin{array}{c}\text { Maksimum } \\
\text { Değer }\end{array}$ & $\begin{array}{c}\text { Standart } \\
\text { Sapma }\end{array}$ & $\begin{array}{c}\text { Değişkenlik } \\
\text { Katsaysis } \\
(\%)\end{array}$ & $\begin{array}{c}\text { Kalite } \\
\text { Değerlendirmesi }\end{array}$ \\
\hline C25/30 & 2320 & 42.39 & 20.3 & 63.2 & 5.84 & 13.78 & Kötü \\
C30/37 & 5472 & 47.01 & 25 & 71.7 & 6.01 & 12.78 & Orta \\
C35/45 & 4896 & 53.81 & 24.3 & 81.2 & 7.00 & 13.01 & İyi \\
\hline
\end{tabular}

Tablo 5'te ise, santral bazlı olarak bir istatistiksel veri kümesi gösterilmiştir. Burada il merkezinde veya ilçelerde faaliyet gösteren ve numune alınan firmalar ayrı ayrı değerlendirilmiştir. Firma bazında bakıldığında $\mathrm{G}$ santralinin $\mathrm{C} 30 / 37$ sınıfındaki verilerinin standardın öngördüğü ortalama değerlerin altında kaldığı görülmektedir. $\mathrm{Bu}$ nedenle bu firma kalite değerlendirilmesine tabi tutulmamıştır. Aynı şekilde değişkenlik katsayılarına bakıldığında en kötü durumun $F$ santraline ait $\mathrm{C} 25 / 30$ sinifinda, en iyi durumunda E santraline ait $\mathrm{C} 30 / 37$ sinıfinda elde edildiği görülmektedir. $G$ firmasının yapı denetimli yapilarda sadece $\mathrm{C} 30 / 37$ beton sinifinda hazır beton ürettiği görülürken, yapı denetimli yapılarda ilçelerde faaliyet gösteren tüm santrallerin C35/45 sınıfinda hazır beton üretmediği görülmektedir. İlçelerde dökülen ve Tablo 3'te görülen C35/45 sınıfındaki hazır betonların il merkezinde faaliyet gösteren santrallerde üretildiği tespit edilmiştir. Genel anlamda il merkezindeki santrallerin değişkenlik katsayılarının ilçe merkezlerinde üretim yapan santrallere göre sinıf bazında birbirlerine yakın olduğu görülebilir. $\mathrm{Bu}$ da ilçe merkezlerindeki kalite sürekliliğinin daha kötü olduğunu göstermektedir.

Tablo 5. İl ve ilçe merkezlerinde üretim yapan santrallere göre istatistiksel veriler

\begin{tabular}{|c|c|c|c|c|c|c|c|c|}
\hline & & \multicolumn{4}{|c|}{ İL MERKEZİ SANTRALLERİ } & \multicolumn{3}{|c|}{ İLÇE SANTRALLERİ } \\
\hline & & $\mathbf{A}$ & B & C & D & $\mathbf{E}$ & $\mathbf{F}$ & $\mathbf{G}$ \\
\hline \multirow{5}{*}{ 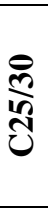 } & ORT & 40,06 & 44,42 & 40,04 & 40,73 & 42,32 & 39,64 & \\
\hline & MIN & 31 & 33,5 & 31,3 & 27,8 & 29,4 & 20,3 & \\
\hline & MAK & 49,4 & 60,8 & 56 & 52,9 & 57,8 & 55,2 & \\
\hline & SS & 4,6 & 5,1 & 4,02 & 4,92 & 5,45 & 5,33 & \\
\hline & $\mathrm{DK}(\%)$ & 11,47 & 11,5 & 10,04 & 12,08 & 12,87 & 13,45 & \\
\hline \multirow{5}{*}{ હે̊ } & ORT & 45,44 & 49,34 & 45,09 & 43,91 & 45,38 & 44,2 & 34,52 \\
\hline & MİN & 30 & 32,5 & 28,3 & 26,2 & 34,9 & 28,4 & 25 \\
\hline & MAK & 58,8 & 65 & 58,9 & 61,6 & 57,1 & 56,3 & 43,6 \\
\hline & SS & 5,12 & 5,3 & 4,91 & 5,43 & 4,25 & 5,08 & 3,87 \\
\hline & $\mathrm{DK}(\%)$ & 11,28 & 10,75 & 10,89 & 12,36 & 9,37 & 11,48 & 11,2 \\
\hline \multirow{5}{*}{$\frac{n}{\stackrel{n}{n}}$} & ORT & 49,9 & 53,64 & 55,65 & 49,34 & & & \\
\hline & MIN & 32 & 33,2 & 32 & 24,3 & & & \\
\hline & MAK & 67,7 & 75,1 & 73,5 & 67,6 & & & \\
\hline & & 5,9 & 5,88 & 6,03 & 5,6 & & & \\
\hline & $\mathrm{DK}(\%)$ & 11,92 & 10,95 & 10,84 & 11,35 & & & \\
\hline
\end{tabular}

Burada (SS) standart sapmayı, (DK) ise yüzde olarak değişim katsayısını göstermektedir. Tablo 5, ACI-214R-1 değerlendirme kriterlerine göre incelendiğinde $\mathrm{C} 25 / 30$ hazır beton sınıfında, $\mathrm{B}, \mathrm{D}$, E ve F santrallerinin ürettiği beton kalitesi "kötü" sinıfinda iken, A ve $\mathrm{C}$ santrallerinin ürettiği $\mathrm{C} 25 / 30$ sinifi hazır betonlar "orta" kalite sınıfındadır. C30/37 sınıfı için bakıldığında, B, C ve E sinıfi santrallerin betonları "iyi", A, D ve F santrallerinin ürettiği hazır betonlar "orta" kalite sınıfındadır. C35/45 hazır beton sınıfına göre bir değerlendirme yapıldığında ise, $B$ ve C santrallerinin ürettiği hazır betonların kalitesi "iyi” sınıfında iken, A ve D santrallerinin ürettiği 
hazır betonlar "orta" kalite sinıfindadır. Santral bazında kalite değerlendirmesi Tablo 6'da verilmiştir.

Tablo 6. Santrallere göre ürettikleri betonları kalite sınıflandırılması

\begin{tabular}{cccc}
\hline \multirow{2}{*}{ SANTRAL } & \multicolumn{3}{c}{ Beton Sınıfi } \\
\cline { 2 - 4 } & C25/30 & C30/37 & C35/45 \\
\hline A & Orta & Orta & Orta \\
B & Kötü & İyi & İyi \\
C & Orta & İyi & İyi \\
D & Kötü & Orta & Orta \\
E & Kötü & İyi & - \\
F & Kötü & Orta & - \\
G & \multicolumn{2}{c}{ Değerlendirilmemiştir } \\
\hline
\end{tabular}

Tablo 6 tüm santrallerin $\mathrm{C} 25 / 30$ beton sinifinda sundukları betonların kalitesinin $\% 67$ oranında kötü olduğunu göstermektedir. $\mathrm{Bu}$ durum beton basınç dayanım testlerinin olumsuz olmasından çok bu sınıftaki minimum ve maksimum değerler arasında fazla fark olmasından doğmaktadır.

Ayrıca sistem üzerinden yapılan incelemede beton numunesi alınan toplam şantiyelerin $\% 5$ 'ne denk gelen 77 şantiyeden alınan hazır betonların basınç dayanım testlerinin standart değerlerin altında çıktığı, bu sonuçların genelde Tablo 1'de verilen 1. Kriteri sağlamadığı tespit edilmiştir. 2019 yılında olumsuz çıkan beton sonuçları ve aylara göre dağ $11 \mathrm{~m} ı$ Tablo 7'de verilmiştir. Bu sonuçlara bakıldığında, düşük değerlerin \%65'i C35/45, \%34'ü C30/37 ve \%1'i C25/30 beton siniflarinda meydana geldiği, ayrıca yaz aylarında daha fazla olumsuz beton sonucuyla karş1laş1ldı̆̆ görülmektedir. Verilen sayılar şantiye sayısını göstermekte olup, bu şantiyelerde dökülen hazır beton miktarının toplamı $4596 \mathrm{~m}^{3}$ 'ü bulmaktadır.
Tablo 7. 2019 y1lında olumsuz çıkan beton sonuçları ve aylara göre dağılımı

\begin{tabular}{l|ccc}
\hline \multicolumn{1}{c}{ C25/30 } & C30/37 & C35/45 \\
\hline Ocak & 1 & - & 1 \\
Şubat & - & 1 & 1 \\
Mart & - & - & 5 \\
Nisan & - & 4 & 5 \\
May1s & - & 3 & 9 \\
Haziran & - & 1 & 6 \\
Temmuz & - & 4 & 10 \\
Ağustos & - & 5 & 5 \\
Eylül & - & - & 1 \\
Ekim & - & 2 & 3 \\
Kasim & - & 4 & 2 \\
Aralık & - & 1 & 2 \\
\hline
\end{tabular}

Isparta merkezli beton santrallerinin ürettikleri betonların yap1 denetim kapsamında olanları Bakanlık onaylı laboratuvarlar tarafindan denetlenirken, aynı zamanda Çevre ve Şehircilik Bakanlığının taşra teşkilatındaki Yapı Malzemeleri Şubesi tarafindan da PGD kapsamında üretilen hazır betonlar denetlenmekte, alınan numuneler İl Müdürlüğü laboratuvarında test edilmektedir. $\mathrm{Bu}$ denetimlerde hem yap1 denetim sistemine tabi olan yapilardan hem de bu sisteme tabi olmayan şantiyelerden numune alınabilmektedir. ÇŞB'nın 27.04.2015 tarihli ve 2015/04 sayıl1 genelgesine (URL-5; 2020) göre her santral yilda en az $3 \mathrm{kez}$ denetime tabi tutulmak zorundadır. Isparta ÇŞM, PGD kapsamında 2019 yılı içerisinde 20 tanesi bir adet, 20 tanesi 2 adet geri kalan 44 tanesi 3 adet numuneden oluşan 84 adet deney testi gerçekleştirmiştir. Toplamda 193 adet olan numunenin 101 adedi C25/30, 66 tanesi C30/37, 25 tanesi $\mathrm{C} 35 / 45$ ve 1 tanesi $\mathrm{C} 20 / 25$ beton sınıflarından oluşmaktadır. Şekil 4, PGD kapsamında yapılan bu denetimlere ait bilgileri göstermektedir. Şekil 4a'da hazır beton sinıflarına göre yapılan denetimlerin dağılım yüzdesi gösterilirken, Şekil 4b'de ise il merkezi ve ilçelerde yapılan denetimlerin oranı verilmiştir.

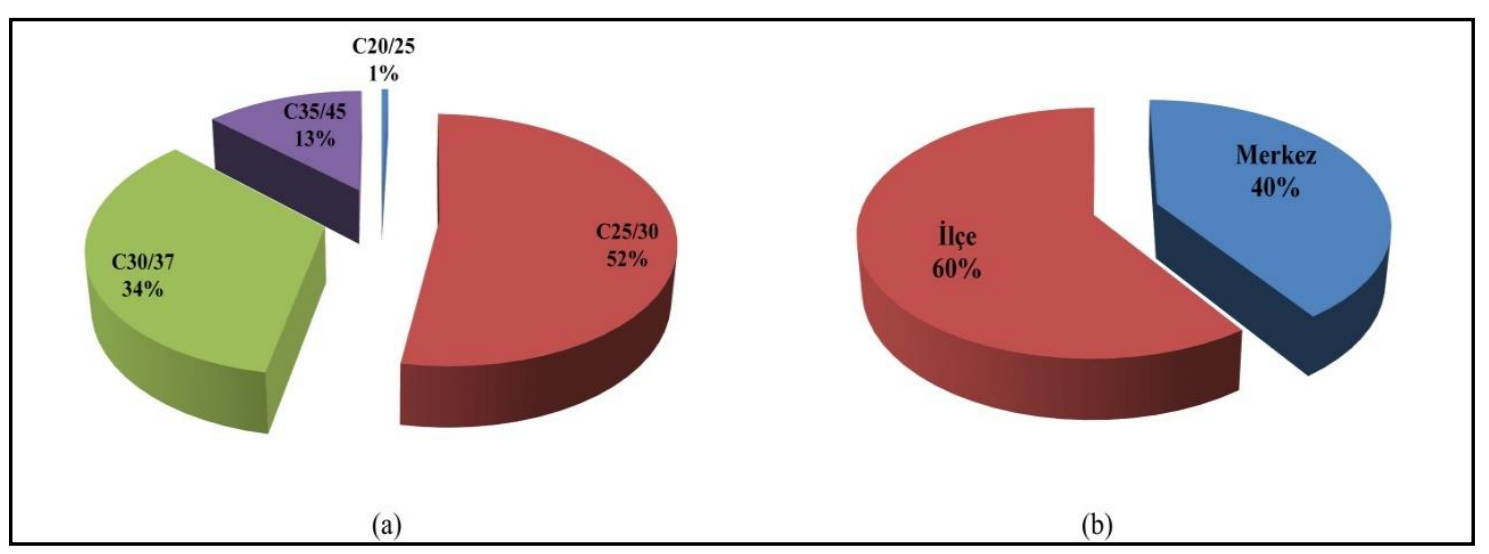

Şekil 4. PGD kapsamında yapılan denetimlere ait bilgiler 
Ayrıca ÇŞM tarafindan yapılan denetimlerin aylara göre dağılımı Şekil 5 'te verilmiştir. Şekil 5 incelendiğinde yllın ilk ve son aylarında denetim yapılmadığı, ayrıca il merkezindeki santrallerin daha az denetlendiği görülmektedir. Her ne kadar bu durum üretilen betonlarla ters bir orant1 sergilese de, il merkezindeki betonların genelde yap1 denetim kapsamındaki yapılarda kullanıldığ ve laboratuvarlar tarafindan test edildiği göz önüne alındığında, ilçelerdeki yapı denetim dışında kalan betonların denetlenmesi açısından olumlu olduğu değerlendirilmektedir.

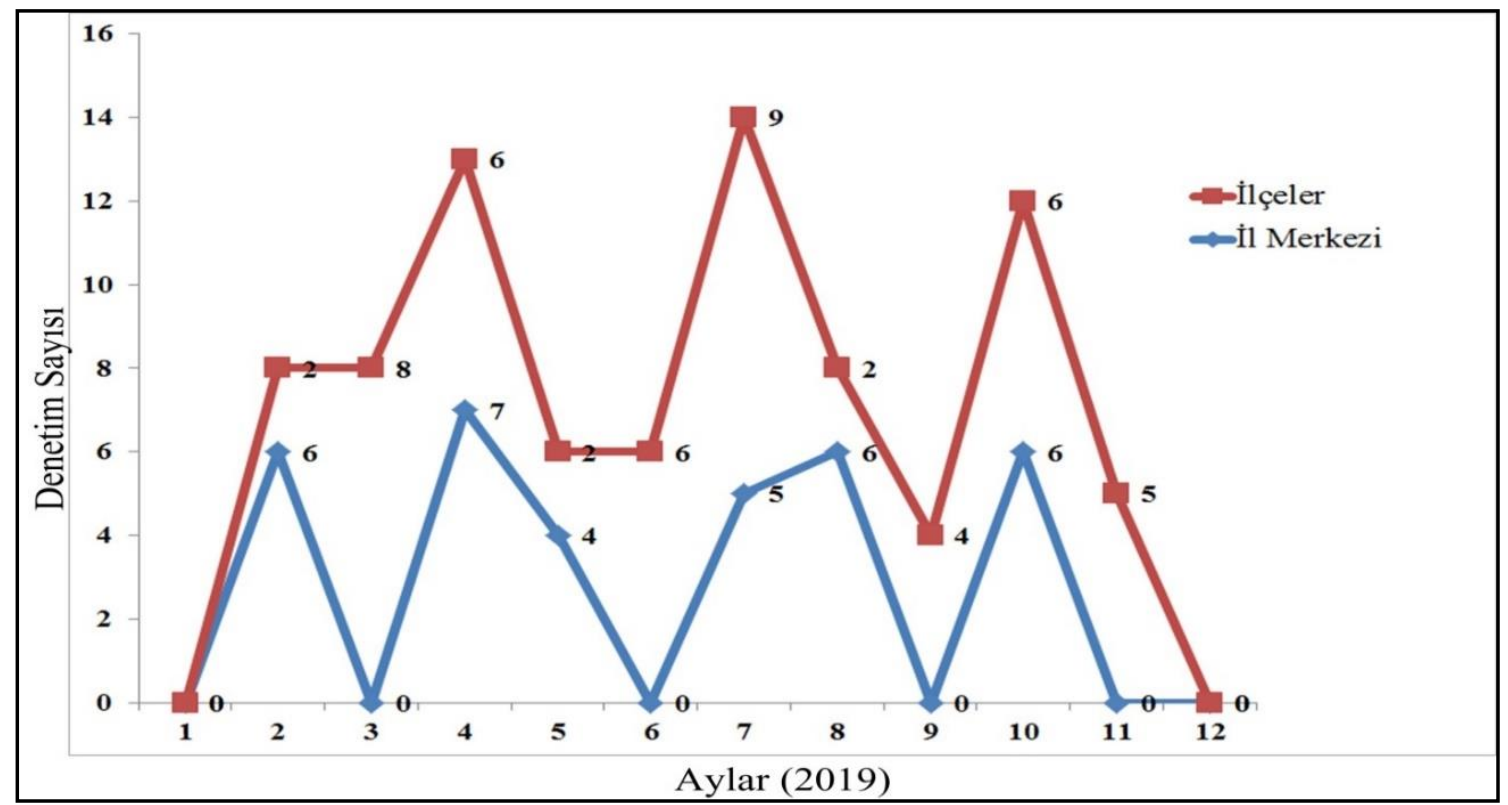

Şekil 5. Aylara göre PGD kapsamında gerçekleştirilen hazır beton denetim sayıları

\section{Tartışma ve Sonuçlar}

$\mathrm{Bu}$ çalışmada Isparta ili genelinde EBİS çerçevesinde, 1540 farklı şantiyeden, 4589 grup ve 12650 tekil numune şeklinde alınan hazır beton numune sonuçlarının basınç dayanımı test sonuçları değerlendirilmiştir. EBİS sonrası laboratuvarlar tarafından gerçekleştirilen kırım sonuçları doğrudan merkez veri tabanına aktarılmakta ve paydaşlar tarafindan anlık olarak izlenebilmektedir. Yap1 denetim ve laboratuvar firmalarının şahitliğinde elektronik etiketlerle konum ve zaman bilgilerinin sayisal olarak izlendiği bu sistemin uygulamada gerçek değerlerin elde edilmesini sağlayacağ 1 ve yap1 sahiplerini olumsuz durumlardan koruyarak daha sağlam yapıların yapılmasına yol açacağı düşünülmektedir. $\mathrm{Bu}$ sisteme geçildikten sonra olumsuz kırım sonuçlarının çok daha fazla raporlanması bu kanaati güçlendirmektedir. Ayrıca sistem üzerinden olumsuz sonuçların ÇŞM'ndeki yap1 denetimlerden sorumlu elemanların erişimine açılması, olumsuz durumlara müdahalelerin daha etkin biçimde yapılmasının önünü açmıştır.

Isparta ili genelindeki hazır beton sonuçları değerlendirildiğinde karakteristik basınç dayanım değerlerinde genel bir problem görülmemekle birlikte, sınıf içerisindeki standart sapma ve değişkenlik katsayısının yüksek olduğu görülmektedir. Özellikle C25/30 beton sınıfindaki hazır betonların sonuçları arasındaki değişkenlik dikkat çekici düzeydedir. $\mathrm{Bu}$ değerlerin yüksekliği sınıf içerisindeki minimum ve maksimum değerler arasındaki farkların büyük olduğunu göstermektedir. Bu ise santrallerin kalite sürdürülebilirliği açısından zayıf olduğunu, farklı zamanlarda farklı değerlere sahip ürün çıkardıklarını göstermektedir. $\mathrm{Bu}$ tür sonuçlar kullanılan malzemelerin uniformluğundaki sürekliliğin sağlanamamasından kaynaklanabildiği gibi santrallerin bu tür bir değerlendirme yapabilecek teknik kapasiteden yoksun olarak da çalışma yapmış olabileceklerinden kaynaklanabilir.

Ayrıca sonuçlara bakıldığında yapı denetimli beton dökümünün il merkezinde $\% 80$ gibi çok yüksek değerde olduğu ilçelerdeki yapıların genelde yap1 denetim kapsamına girmeyecek büyüklükte olduğu görülmektedir. Aslında 4708 sayılı Yapı Denetim Hakkında Kanunda belirtilen nüfusu 5.000 kişinin altında olan belediyelik yerlerde veya belediye mücavir alanlar dışındaki $500 \mathrm{~m}^{2}$ ye kadar olan binaların yap1 denetim sistemi dışında bırakılması, bu yapılarda kullanılan hazır betonların denetim dışı kalmasına 
yol açmaktadır. Bodrum katı dışında en çok iki katlı ve inşaat alanı 500 metrekareyi geçmeyen bu yapılarda da kullanılan hazır betonların bir şekilde laboratuvar denetimine sokulması olas1 depremlerde kırsal bölgelerdeki karşılaşılabilecek yüksek hasarların önüne geçebilecektir. İl Müdürlüğünün daha çok ilçelerde denetim gerçekleştirmesi bu alandaki olumsuz etkiyi ortadan kaldırmaya yönelik pozitif bir adım olarak düşünülebilir.

Sistemin olumsuz raporladığı sonuçlar hakkında Yap1 Denetim firmaları tarafindan karot alımı gerçekleştirilerek yeniden bir değerlendirme yapilmakta, bu durumda ise genelde olumlu rapor verilmektedir. PGD kapsamında yapılan denetimlerde olduğu gibi olumsuz bir durumla karşılaşılması durumunda doğrudan idari yaptırıma gidilmesi hazır beton firmalarının daha dikkatli üretim yapmasını, alınan numunelerin standartlara uygun olarak alınmasinı, saklanmasını ve taşınmasını netice verecektir.

Sistem tarafindan olumsuz olarak raporlanan test sonuçlarına bakıldığında numune alınan toplam şantiyelerin \%5'inden alınan sonuçların negatif olduğu, bununda azımsanmayacak bir değer olduğu dikkat çekmektedir. Ayrıca bu olumsuz sonuçların \%65 gibi bir oranının C35/45 sınıfinda çıkması dikkat çekicidir. Çok katlı inşaatların arttığ1 günümüzde C35/45 sınıfindaki kullanımlar gittikçe artmakta olup, bu sinıfta üretilen betonların özellikle üretim kalitesinin s1k1 tutulmasının gerektiği görülmektedir. EBİS öncesi bu kadar olumsuz bir durumun rapor edilmemesi ise laboratuvarların güvenirliliği açısından sorgulanması gereken ayrı bir husustur.

Sistem üzerinden erişilen raporlarda olumsuz olarak dikkat çeken bir hususta laboratuvar görevlileri tarafindan saat, sicaklık ve slump değerlerinin sabit olarak girilmesinin tercih edilmesidir. Bazı raporlarda gün içerisinde çok uzun bir zaman süresinde dökümü gerçekleştirilen raporlamalarda sicaklık değerlerinin, slump değerlerinin hiç değişmemesi bu değerlerin görevliler tarafindan rastgele girildiğini ispatlamaktadır. Şifahi olarak bu görevlilerle gerçekleştirilen görüşmelerde bu değerlerin sistem tarafindan önemsenmediğini, bu nedenle doğru değerlerin girilmediğini beyan etmeleri negatif bir durum olarak görülmektedir. El terminallerine yüklenecek bir program vasitasıyla sicaklık ve saat bilgilerinin otomatik olarak sistem tarafindan yüklenilmesi bu verilerin güvenirliliğini artıracaktır.
Sonuç olarak EBİS sonrası elde edilen verilerin bu sistem öncesi verilere oranla daha güvenilir olacağ 1 , paydaşlar tarafindan raporlanan olumsuz durumları azaltacağı, yap1 sahiplerinin istenilen sınıf dışında bir hazır beton kalitesiyle karşılaşmalarını azaltacağı düşünülmektedir. Sistemin çok yeni olması, zamanla aksayan yönlerinin düzeltilerek daha aktif bir kullanım sağlayacağ1, bununda hazır beton kalitesine olumlu olarak yansıyacağı değerlendirilmektedir.

\section{Teșekkür}

Bu çalışmanın verilerini değerlendirmek için izin veren Isparta Çevre ve Şehircilik İl Müdürü Sayın Abdullah BORCA'ya teşekkür ederim.

\section{Kaynaklar}

ACI Committee 214R-1, 2011. Guide to Evaluation of Strength Test Results of Concrete: Michigan, American Concrete Institute, Farmington Hills. $20 \mathrm{p}$.

Akakın, T., Kılınç, C., Işık, A. ve Zengin, H., 2013. Hazır Beton Sektörü ve Beton Kullanımındaki Gelişmeler. Hazır Beton Dergisi, 116, 66-72.

Akyüz, S. ve Uyan, M., 1989. İstanbul ve Çevresindeki Betonların Niteliği Üzerine Bir Deneme, 1. Ulusal Beton Kongresi, Mayis 1989, İstanbul, Türkiye, s.160-171.

Davraz, M., Başpınar, E. ve Ceylan, H., 2012. Yap1 Denetim Kurumları Öncesi Isparta ve Yakın Civarındaki Hazır Beton Kalitesi. Teknik Bilimler Dergisi, 2(1), 18-25.

Dündar, B., Atabey, İ. ve Ümit, Y., 2017. Osmaniye İlinde Hazır Beton Santrallerinde Üretilen Beton Kalitelerinin İstatistiksel Olarak Değerlendirilmesi. Selçuk-Teknik Dergisi, 16(2), 71-86.

Ergün, A. ve Başaran, V., 2011. Afyonkarahisar'da Üretilen Hazır Beton Kalitelerinin Değerlendirilmesi. Afyon Kocatepe Üniversitesi Fen ve Mühendislik Bilimleri Dergisi, 10(2), 51-58.

Firat, F. K., 2005. Antalya Yöresinde Kullanılan Betonun Niteliğinin İstatistiksel Olarak İncelenmesi, Antalya Bölgesinin İnşaat Mühendisliği Sorunları Kongresi, Eylül 2005, Antalya, Türkiye, s.165-172.

Memiş, S., Mütevelli, İ.G. ve Yılmazoğlu, M.U., 2016. Sinop İlinde Üretilen Hazır Betonların İstatistiksel Olarak Değerlendirilmesi. Engineering Sciences, 11(4), 83-92. doi:10.12739/NWSA.2016.11.4.1A0365. 
Memiş, S., Yılmazoğlu, M.U. ve Mütevelli, İ.G., 2016b. Kastamonu İlinde Kullanılan Betonların Nicel Analizi. Düzce Üniversitesi Bilim ve Teknoloji Dergisi, 4(2), 756-764.

Öztoprak, B., Sözen, Ş. ve Çavuş, M., 2018. Bolu Bölgesindeki Hazır Beton Tesislerinin Durumu ve Beton Kalitesini Etkileyen Faktörler. Gaziosmanpaşa Bilimsel Araştırma Dergisi, 7(3), 1-11.

Topçu, İ.B. ve Demir, A., 2004. Eskişehir'de Dökülen Betonların Niteliği Üzerine İstatistiksel Bir Değerlendirme. Eskişehir Osmangazi Üniversitesi Mühendislik ve Mimarlık Fakültesi Dergisi, 17(2), 41-50.

Topçu, İ.B. ve Boğa, A.R., 2005. Eskişehir'deki Hazır Beton Firmalarının Beton Kalitelerinin İstatistiksel Değerlendirilmesi. Eskişehir Osmangazi Üniversitesi Mühendislik ve Mimarlık Fakültesi Dergisi, 18(1), 19-31.

Topçu, İ.B. ve Uzunömeroğlu, A., 2019. Ankara'da Üretilen Hazır Betonların İstatistiksel Analizi. Nicel Bilimler Dergisi, 1(1), 16-42.

Topçu, İ.B. ve Ateşin, Ö., 2013. Kütahya'da Üretilen Betonların İstatistiksel Olarak Değerlendirilmesi. Dumlupınar Üniversitesi Fen Bilimleri Enstitüsü Dergisi, 30, 56-63.

TSE 13515:2019. TS EN 206'nın uygulanmasına yönelik tamamlayıcı standart, Türk Standartları Enstitüsü, Ankara.

Uğur, T. ve Güleç, A., 2014. Harç, Sıva ve Diğer Kompozit Malzemelerde Kullanılan Bağlayıcılar ve Özellikleri. Restorasyon ve Konservasyon Çalışmaları Dergisi, 17, 77-91.

Uğurlu, A., 2013. Depremde Beton ve Davranışı. İMO Mühendislik Haberleri, 476(2), 57-63.

URL-1, https://www.thbb.org/sektor/istatistikler/ 2018 Y1lı Hazır Beton İstatistikleri, 2019. Türkiye Hazır Beton Birliği. 15 Mart 2020.

URL-2, https://www.mevzuat.gov.tr/Metin.Aspx? MevzuatKod=7.5.24468\&MevzuatIliski=

$0 \&$ sourceXmlSearch =Deprem \%20Y\%C3\%B6netmeli\%C4\%9Fi 2018 Türkiye Bina Deprem Yönetmeliği. 15 Mart 2020.

URL-3, https://ebistr.com/pages/publicDocument. 07 Ocak 2020.

URL-4,

https://webdosya.csb.gov.tr/db/isparta/menu/faal iyet-raporu--2019_20190321082946.pdf. Isparta Çevre ve Şehircilik İl Müdürlüğü Faaliyet Raporu. 07 Ocak 2020.

URL-5, https://yapiisleri.csb.gov.tr/beton-numunelerihakkinda-genelge-i-5165. 17.09.2020 